\title{
Formation and Properties of Ni-Based Amorphous Metallic Coating Produced by HVAF Thermal Spraying
}

\author{
Ai Ping Wang ${ }^{1}$, Tao Zhang ${ }^{2}$ and Jian Qiang Wang ${ }^{1, *}$ \\ ${ }^{1}$ Shenyang National Laboratory for Materials Science, Institute of Metal Research, CAS, Shenyang 110016, P. R. China \\ ${ }^{2}$ State Key Laboratory for Corrosion and Protection, Institute of Metal Research, CAS, Shenyang 110016, P. R. China
}

\begin{abstract}
A highly dense $\mathrm{Ni}_{59} \mathrm{Zr}_{20} \mathrm{Ti}_{16} \mathrm{Si}_{2} \mathrm{Sn}_{3}$ partial amorphous metallic coating, about $500 \mu \mathrm{m}$ thick, was fabricated by means of HVAF (High Velocity Air Fuel) thermal spraying. Amorphous alloy powders produced by using gas atomization were used for HVAF thermal spraying to produce an amorphous metallic coating. Microstructural investigation showed that crystallization and oxidation occurred during thermal spraying. The volume fraction of amorphous phase in the coating is $44 \%$ as determined by using differential scanning calorimetry. Studies of the wear and corrosion properties of the resulting coating were also performed. The corrosion characteristics of the coating are sensitive to aqueous solutions selected. It exhibits good corrosion resistance in $0.05 \mathrm{kmol} / \mathrm{m}^{3} \mathrm{H}_{2} \mathrm{SO}_{4}+0.05 \mathrm{kmol} / \mathrm{m}^{3} \mathrm{Na}_{2} \mathrm{SO}_{4}$ aqueous solution due to low passive current density and wide passive region.
\end{abstract}

(Received September 8, 2004; Accepted March 4, 2005; Published May 15, 2005)

Keywords: high velocity air fuel, amorphous metallic coating, wear resistance, corrosion resistance

\section{Introduction}

Metallic glasses have attracted much attention due to their unique properties that cannot be obtained in their crystalline counterparts. In most cases, high cooling rates (e.g., $10^{4}$ $10^{6} \mathrm{~K} / \mathrm{s}$ ) are required for the formation of an amorphous phase from the liquid state, resulting in small thickness or diameter sections in the form of powders, ribbons or wires. Thus, the application of metallic glass as engineering materials has been limited. Over the last ten years, a number of new metallic glass having high glass-forming ability and wide supercooled liquid region before crystallization have been developed. ${ }^{1-4)}$ Such alloys can be fabricated with large dimensions ranging from millimeters to centimeters at critical cooling rate of $1-100 \mathrm{~K} / \mathrm{s}$ for glass formation. The high strength and high elastic strain limit of these bulk metallic glasses make these materials a good candidate for structural applications.

The plastic deformation of metallic glasses, because of the absence of crystal slip, is quite unlike those of conventional crystalline metals. They show two distinct modes of plastic flow. At temperature above glass transition, there is viscous flow, which opens up the possibility of superplastic forming. At ambient temperature, the plastic flow is concentrated into shear bands, leading to catastrophic shear failure immediately following yield. This work-softening has limited structural application of metallic glasses exploiting their high yield stress, which makes them more attractive as coatings than as bulk materials. ${ }^{5)}$ With combined good wear and corrosion resistance. ${ }^{6-8)}$ metallic glasses are ideal candidates for coatings to withstand aggressive environments.

Thermal spraying is a widely recognized industrial method for producing protective coatings, in which a micro-solidification consolidation process occurs by melting and rapid cooling of alloy powders. Partial amorphous metallic coatings in $\mathrm{Ni}$ - and $\mathrm{Fe}$-based alloy systems have been produced

${ }^{*}$ Corresponding author, E-mail: jqwang@imr.ac.cn currently by plasma spray and high velocity oxygen fuel (HVOF) spray technique. ${ }^{9-11)}$ Since the formability of amorphous metallic coatings are related to original powder characteristics as well as processing variables, alloy systems with higher glass-forming ability are much easier to reach fully amorphous metallic coatings. In this work, attempts were made to evaluate the formability and the properties of amorphous metallic coatings produced by thermal spray. A $\mathrm{Ni}_{59} \mathrm{Zr}_{20} \mathrm{Ti}_{16} \mathrm{Si}_{2} \mathrm{Sn}_{3}$ alloy, as one of the highest glass-forming ability in Ni-based alloys, ${ }^{12)}$ was selected. To improve the coating quality, the activated combustion high velocity air fuel (AC-HVAF) spray method, which has high spraying particle velocity typically of $700-850 \mathrm{~m} / \mathrm{s}$, was adopted to produce amorphous metallic coating.

\section{Experimental Method}

A $\mathrm{Ni}_{59} \mathrm{Zr}_{20} \mathrm{Ti}_{16} \mathrm{Si}_{2} \mathrm{Sn}_{3}$ master alloy was prepared by induction-melting high-purity elemental constituents (Ni: 99.9\%, Zr: $99.8 \%$, Ti: $99.9 \%$, Si: $99.999 \%$, Sn: $99.9 \%$ ) in a yttria-stabilized zirconia crucible under an argon atmosphere. The homogeneous molten alloy was cast into a water-chilled $\mathrm{Cu}$ mold. The $\mathrm{Ni}_{59} \mathrm{Zr}_{20} \mathrm{Ti}_{16} \mathrm{Si}_{2} \mathrm{Sn}_{3}$ powders were produced by high-pressure Ar gas atomization at a dynamic pressure of 8.1 MPa after heating to $1473 \mathrm{~K}$ using a close-coupled annulus nozzle with a melt delivery inner diameter of $3 \mathrm{~mm}$. The atomized powders were sieved according to conventional sieve analysis and divided into different size ranges. The contents of oxygen and nitrogen contents in the powders were analyzed by a Nitrogen/Oxygen determinator (Leco TC-436, St. Joseph, MI).

Activated combustion high-velocity air-fuel (AC-HVAF) spray systems/SB500SF (UniqueCoat Technologies LLC, USA) were used to deposit coatings onto low carbon steel coupons. The details of AC-HVAF process have been described elsewhere. ${ }^{13)}$ Briefly, $\mathrm{Ni}_{59} \mathrm{Zr}_{20} \mathrm{Ti}_{16} \mathrm{Si}_{2} \mathrm{Sn}_{3}$ powder particles with diameters ranging from 16 to $45 \mu \mathrm{m}$ were heated to around $1373 \mathrm{~K}$, then accelerated and impacted upon low carbon steel substrate at a velocity of $\sim 700 \mathrm{~m} / \mathrm{s}$. Such a 
high particle spray velocity was due to the combustion of a mixture of $0.6 \mathrm{MPa}$ compressed air and $0.4 \mathrm{MPa}$ propane within very small combustion chamber of the AC-HVAF gun. The substrates selected were low carbon steel with a dimension of $20 \times 20 \times 4 \mathrm{~mm}$. The stand-off distance of particle spraying was $150 \mathrm{~mm}$, and coating with thickness of $\sim 500 \mu \mathrm{m}$ was deposited.

For comparison, the melt-spun $\mathrm{Ni}_{59} \mathrm{Zr}_{20} \mathrm{Ti}_{16} \mathrm{Si}_{2} \mathrm{Sn}_{3}$ ribbon with $\sim 3 \mathrm{~mm}$ width and $\sim 50 \mu \mathrm{m}$ thickness and electroplated chromium sample with $\sim 10 \mu \mathrm{m}$ thickness were prepared. The microhardness of the coating, ribbon and electroplated chromium samples was measured on a tester (MVK-H3) with loads of 100, 25 and $5 \mathrm{~g}$ applied respectively for duration of $10 \mathrm{~s}$. The values given are the average 10 measurements. The wear tests were carried out using ball-on-disk type sliding wear apparatus (SRVIII). The counter ball was GCr15 steel.

The corrosion properties of coating samples were evaluated by electrochemical measurement on a Potentiostat/ Galvanostat (EG\&G Princeton Applied Research Model 273). Prior to electrochemical measurements, the samples were degreased in aceton, washed in distilled water and dried in air. Electrochemical measurements were conducted in a three-electrode cell using a platinum counter electrode and an $\mathrm{Ag} / \mathrm{AgCl}$ reference electrode. Potentiodynamic polarization curves were measured with a potential sweep rate of $0.33 \mathrm{mV} / \mathrm{s}$ in aqueous solutions open to air at $298 \mathrm{~K}$ after immersing the samples for several minutes, when the opencircuit potential became almost steady.

The microstructure of the powders and as-deposited coatings was characterized by scanning electron microscopy (SEM) (JMS-6301) equipped with energy dispersive spectroscopy (EDS) and transmission electron microscopy (TEM) (JEM-2000FXII). Thin foil samples for TEM observation were cut from the deposited coating by electro-spark discharge, mechanical ground and thinned by ion milling. X-ray diffraction (XRD) analysis of the powders and asdeposited coatings was performed on an X-ray diffractometry (Rigaku D/max 2400) with $\mathrm{CuK} \alpha$ radiation. Using image analysis on optical microscopy (MEF-4), percentage of porosity in the coatings was evaluated. The thermal stability of the atomized powders and the coatings was examined in differential scanning calorimeter (Perkin-Elmer DSC-7) in a continuous heating mode at a rate of $20 \mathrm{~K} / \mathrm{min}$.

\section{Results and Discussion}

\subsection{Gas-atomized powders and HVAF coatings}

Figure 1 shows XRD patterns of the $\mathrm{Ni}_{59} \mathrm{Zr}_{20} \mathrm{Ti}_{16} \mathrm{Si}_{2} \mathrm{Sn}_{3}$ atomized powders with particle size of $<160 \mu \mathrm{m}$ and meltspun ribbons. It exhibits a broad halo peak in the $2 \theta=$ $33-48^{\circ}$ for the melt-spun ribbons and powders with particle size below $50 \mu \mathrm{m}$, indicating the complete glass formation, whereas a small amount of crystalline phases existed in the powders with a size range of $>50 \mu \mathrm{m}$. SEM micrographs of the as-atomized powders shown in Fig. 2, indicate that most of the particles are in near-spherical form along with some satellites attached. Featureless structure could be observed on the cross-section of the powder with a particle size below $50 \mu \mathrm{m}$, confirming its fully metallic glass nature, which is in

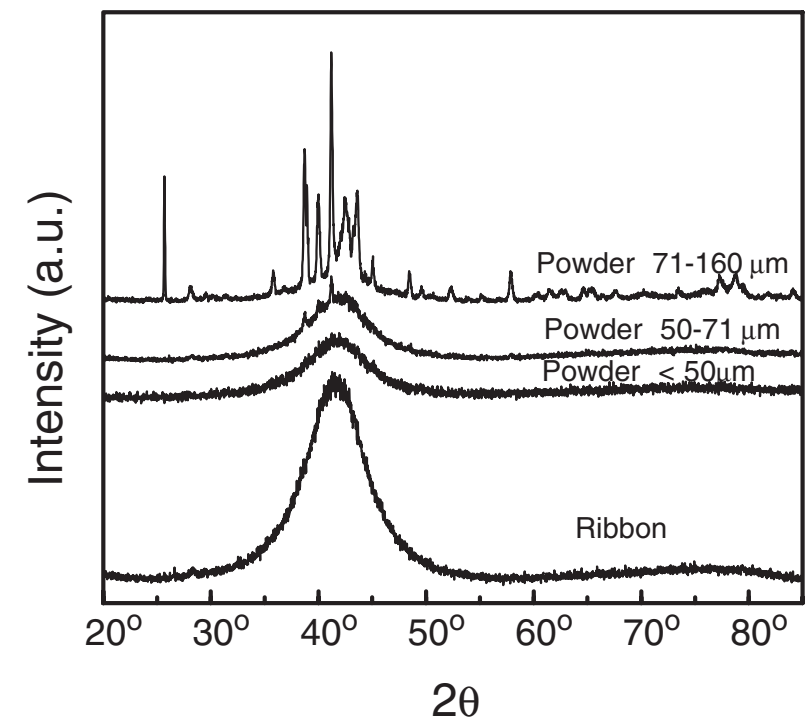

Fig. 1 XRD patterns of the $\mathrm{Ni}_{59} \mathrm{Zr}_{20} \mathrm{Ti}_{16} \mathrm{Si}_{2} \mathrm{Sn}_{3}$ amorphous alloy: meltspun ribbon and atomized powders with different particle size.

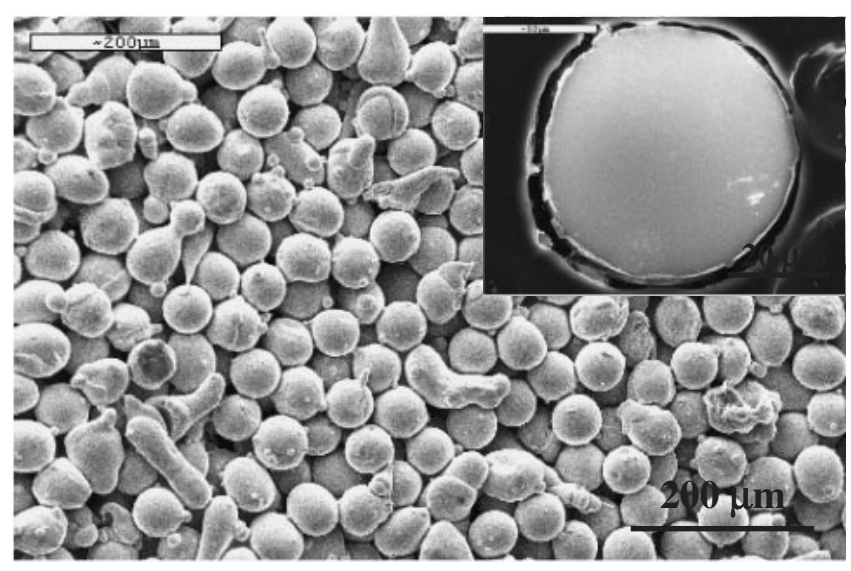

Fig. 2 SEM image of the atomized powders $(<50 \mu \mathrm{m})$, in which most of the particles are in near-spherical form along with some satellites attached. Inset is a typical cross-section of powders.

good agreement with XRD results.

DSC traces for the $\mathrm{Ni}_{59} \mathrm{Zr}_{20} \mathrm{Ti}_{16} \mathrm{Si}_{2} \mathrm{Sn}_{3}$ powders $(<50 \mu \mathrm{m})$ and ribbons at a heating rate of $20 \mathrm{~K} / \mathrm{min}$ were shown in Fig. 3. Both samples exhibit a single exothermic reaction during heating. Compared with the ribbons, the powders showed almost the same glass transition temperature $\left(T_{\mathrm{g}}=\right.$ $821 \mathrm{~K})$ and onset crystallization temperature $\left(T_{\mathrm{x}}=874 \mathrm{~K}\right)$ ). The presence of a wide supercooled liquid region of $\Delta T_{\mathrm{x}}=53 \mathrm{~K}$ and high glass-forming ability in this alloy system make the amorphous alloy powders suitable for the preparation of amorphous metallic coatings.

Because of rapid cooling rate (near $10^{6} \mathrm{~K} / \mathrm{s}$ ) ${ }^{14,15}$ ) process of the thermal spraying, one would expect complete amorphization in the coating of a glass-forming alloy with the high GFA $(\sim 3 \mathrm{~mm})$ of the alloy composition of $\mathrm{Ni}_{59} \mathrm{Zr}_{20} \mathrm{Ti}_{16} \mathrm{Si}_{2} \mathrm{Sn}_{3} .{ }^{12)}$ However, a XRD pattern given in Fig. 4 for that as-deposited coating shows that some crystalline and oxide phases have appeared in the coating. This shows crystallization and oxidation occurred during the 


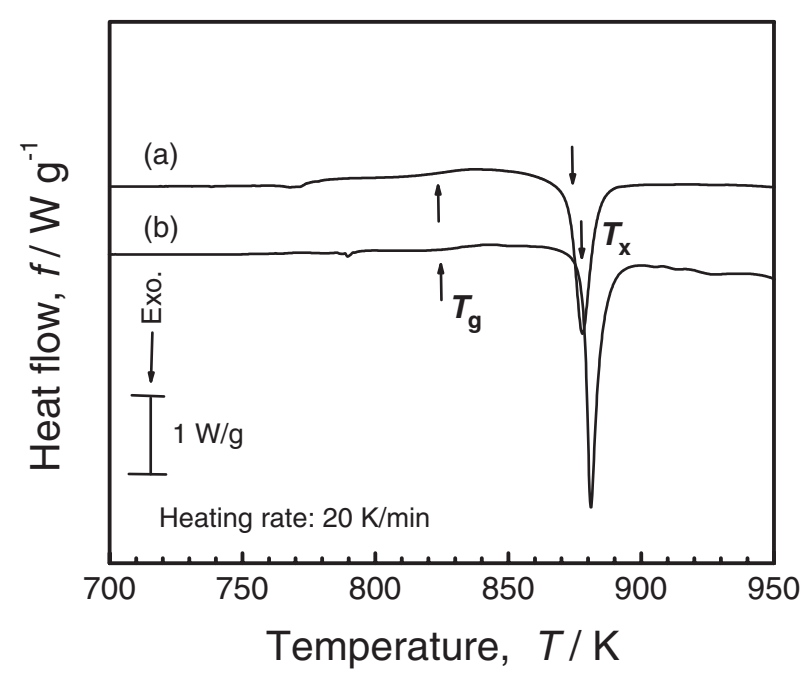

Fig. 3 DSC traces of the $\mathrm{Ni}_{59} \mathrm{Zr}_{20} \mathrm{Ti}_{16} \mathrm{Si}_{2} \mathrm{Sn}_{3}$ amorphous alloy (a) atomized powders $(<50 \mu \mathrm{m})$ and (b) melt-spun ribbon.

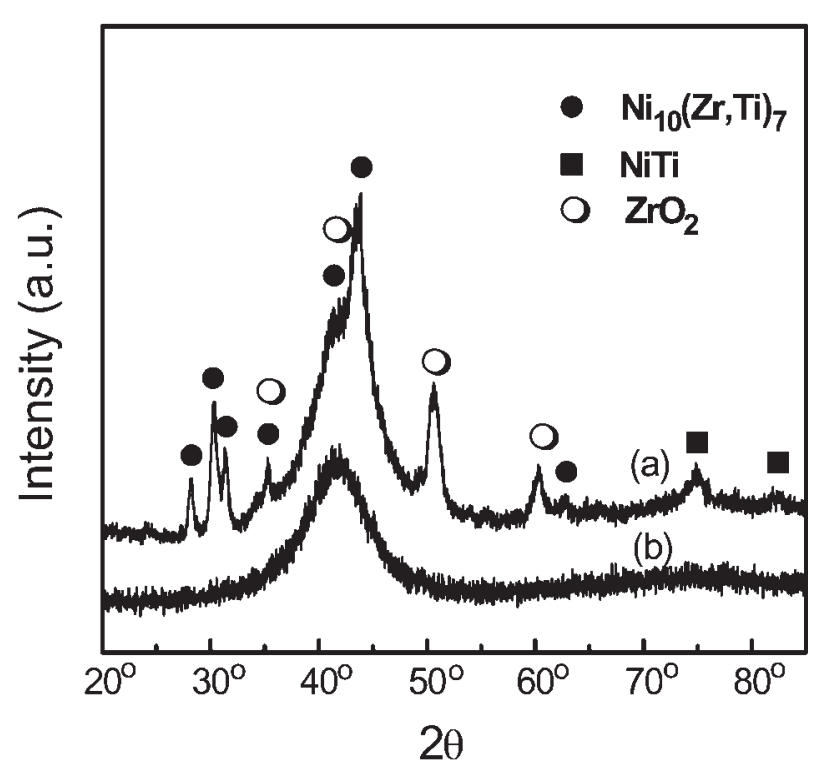

Fig. 4 XRD patterns of the as-deposited coating (a) and the gas-atomized amorphous alloy powders $(<50 \mu \mathrm{m})(\mathrm{b})$.

HVAF thermal spraying. Crystallization may be interpreted that the powders are not full melted due to the fact that the temperature of HVAF process was not high enough $(\sim 1373 \mathrm{~K})$ and the solidified deposit is exposed to a high temperature flame, as well as to adiabatic recalescence occurred due to successive solidification of one droplet upon another. Oxidation is because of air existed in this HVAF thermal spraying process. The oxygen content in the coating analyzed by a Nitrogen/Oxygen determinator was $4.3 \%$.

A SEM image of a typical region from a cross-section of a coating is shown in Fig. 5(a). This reveals microstructural features which were common to HVOF thermal spray process. Some limited porosity is visible as very dark contrast regions but generally the coating has a dense structure. The porosity of the coating analyzed by optical microscopy was $0.4 \%$. Figure 5 (b) illustrates a backscattered electron (BSE) scan for the elemental constituents of the
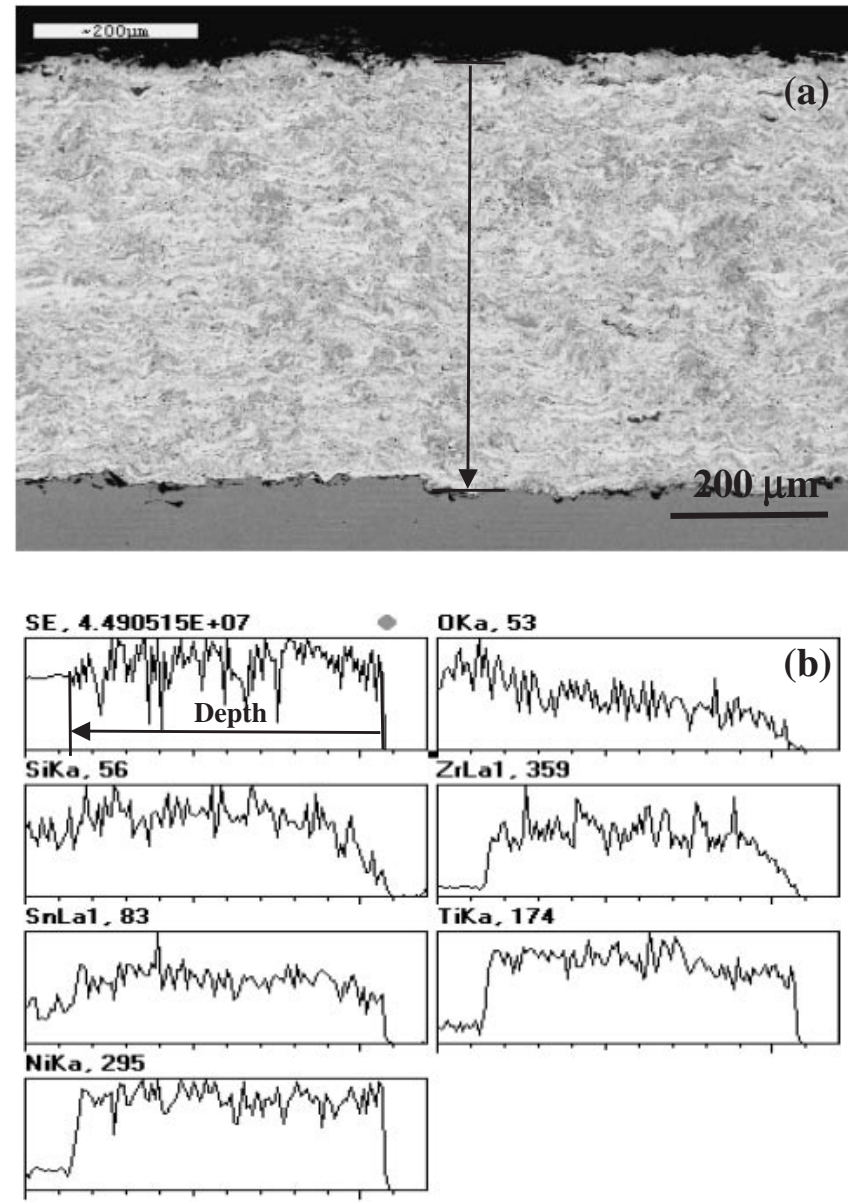

Fig. 5 (a) Backscattered electron (BSE) image of a cross-section of assprayed coating and (b) BSE scans of the elemental contents along coating depth.

coating: $\mathrm{Ni}, \mathrm{Zr}, \mathrm{Ti}, \mathrm{Si}, \mathrm{Sn}$ and $\mathrm{O}$. One can see that the elemental concentration distributions except for oxygen are almost homogenous along the depth of the coating, while the oxygen content increases with the depth of the coating.

Figure 6 shows the TEM images of the coating from the place of about $300 \mu \mathrm{m}$ from the top. The metallic glass matrix and crystalline and oxide phases are clearly seen. Figure 7 shows the DSC traces for the coating and the gas atomized amorphous alloy powders. The volume fraction of amorphous phase in the coating was calculated by comparison of the heat of crystallization $(\Delta H)$ of the powders and the coating:

$$
\text { am. } \%=\frac{\Delta H_{\text {coating }}}{\Delta H_{\text {powders }}}=\frac{-22.1 \mathrm{~J} / \mathrm{g}}{-50.3 \mathrm{~J} / \mathrm{g}}=44 \%
$$

\subsection{Microhardness and wear resistance}

Figure 8 compares the wear resistance of the coating, the amorphous alloy ribbon of same composition, and the electroplated $\mathrm{Cr}$ in correlation with their microhardness by using the same ball-on-disk devices. The value of wear resistance, $R_{\mathrm{w}}$, can be calculated using the Rabinowitz relationship $R_{\mathrm{w}}=S \times N / V_{\mathrm{w}},{ }^{16)}$ where $V_{\mathrm{w}}$ is the wear volume measured with a calibrated optical microscopy, $S$, the sliding distance, $N$, the normal load. 


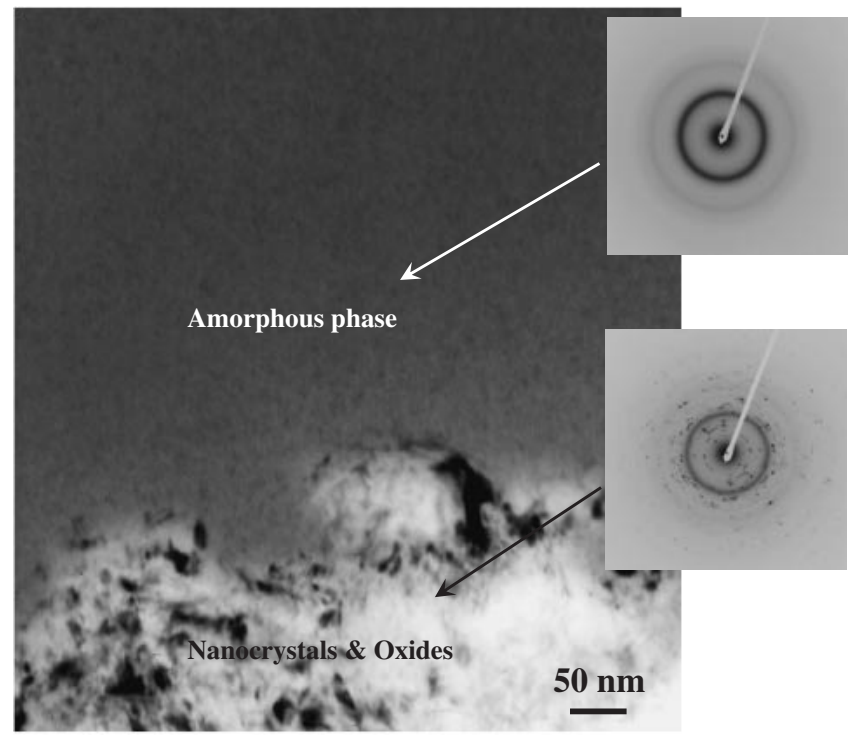

Fig. 6 Dark-field TEM image and selected area electron diffraction (SAED) patterns of a coating taken from the place of $\sim 300 \mu \mathrm{m}$ from the top. SAED patterns indicate the existence of amorphous and crystalline phase.

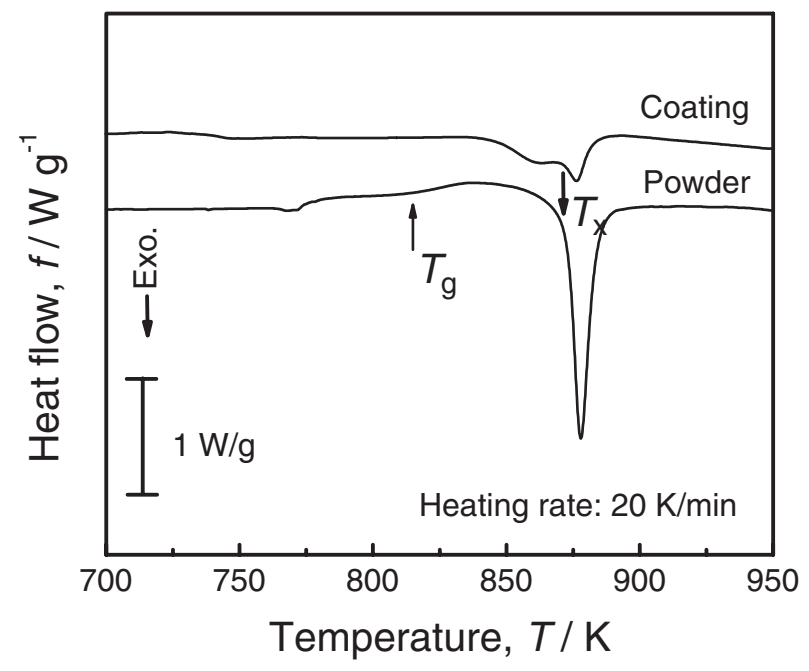

Fig. 7 DSC traces of the $\mathrm{Ni}_{59} \mathrm{Zr}_{20} \mathrm{Ti}_{16} \mathrm{Si}_{2} \mathrm{Sn}_{3}$ amorphous alloy powders and coating.

It could be seen that the wear resistance of the coating is higher than that electroplated $\mathrm{Cr}$ specimen. This result indicates that our amorphous metallic coating can potentially replace electroplated $\mathrm{Cr}$. This is of interest as electroplated $\mathrm{Cr}$ should be replaced due to the pollution in the process.

\subsection{Corrosion resistance}

Figure 9 shows the potentiodynamic polarization curves of the amorphous alloy ribbon and coating in five aqueous solutions: $0.1 \mathrm{kmol} / \mathrm{m}^{3} \mathrm{HCl}, 0.05 \mathrm{kmol} / \mathrm{m}^{3} \mathrm{H}_{2} \mathrm{SO}_{4}+0.05$ $\mathrm{kmol} / \mathrm{m}^{3} \mathrm{Na}_{2} \mathrm{SO}_{4}, 0.1 \mathrm{kmol} / \mathrm{m}^{3} \mathrm{NaOH}+0.1 \mathrm{kmol} / \mathrm{m}^{3} \mathrm{NaCl}$, $0.1 \mathrm{kmol} / \mathrm{m}^{3} \mathrm{NaOH}+0.1 \mathrm{kmol} / \mathrm{m}^{3} \mathrm{Na}_{2} \mathrm{SO}_{4}$, which are aggressive and passive system in acid and alkali aqueous solutions, respectively, and $3.5 \% \mathrm{NaCl}$ which simulates seawater. The electroplated $\mathrm{Cr}$ is used for comparison. It can

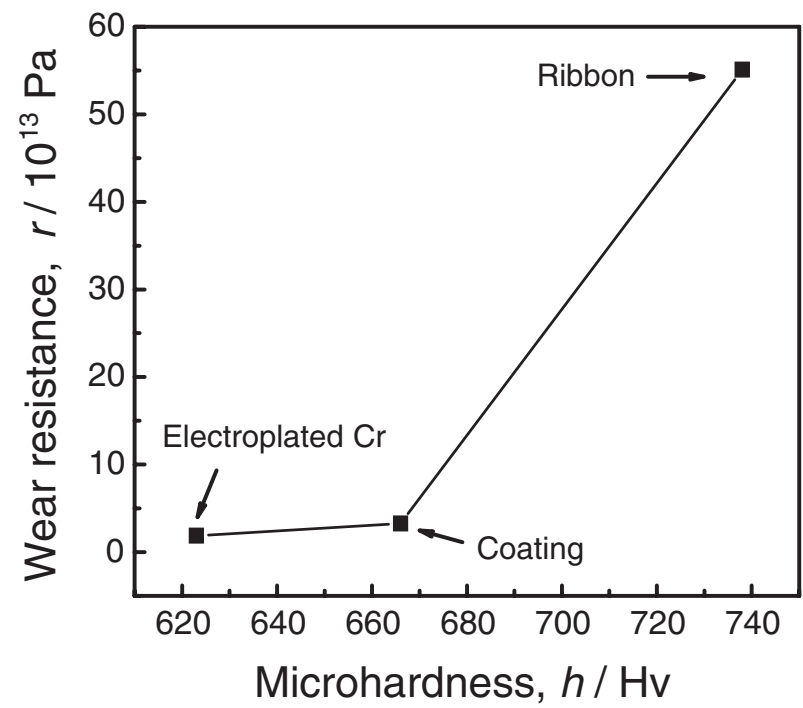

Fig. 8 Wear resistance of the $\mathrm{Ni}_{59} \mathrm{Zr}_{20} \mathrm{Ti}_{16} \mathrm{Si}_{2} \mathrm{Sn}_{3}$ amorphous alloy ribbon, coating and the electroplated $\mathrm{Cr}$ samples.

be seen that the corrosion resistance of the samples depends on solution chemistry.

Both the amorphous alloy ribbon and coating have good corrosion resistance in $0.05 \mathrm{kmol} / \mathrm{m}^{3} \mathrm{H}_{2} \mathrm{SO}_{4}+0.05 \mathrm{kmol} /$ $\mathrm{m}^{3} \mathrm{Na}_{2} \mathrm{SO}_{4}$ aqueous solution (Fig. 9(a)). They exhibit good passive behavior in this solution. The corrosion current density and passive current density are about $10^{-3} \mathrm{~A} / \mathrm{m}^{2}$ and $10^{-2} \mathrm{~A} / \mathrm{m}^{2}$ for the ribbon, and $5 \times 10^{-2} \mathrm{~A} / \mathrm{m}^{2}$ and $3 \times$ $10^{-1} \mathrm{~A} / \mathrm{m}^{2}$ for the coating, respectively. The ribbon remains passivation at a potential of $1.2 \mathrm{~V}$, indicating its high corrosion resistance. The coating has a wide passive region until the transpassive dissolution of passive film at about $0.6 \mathrm{~V}$, also illustrating its good corrosion property. However, the corrosion resistance of the coating is inferior to the amorphous alloy ribbon of same composition, this may be interpreted that the structure of the coating is not homogenous as that of the amorphous alloy ribbon due to crystallization and oxidation occurred during thermal spraying.

In $0.1 \mathrm{kmol} / \mathrm{m}^{3} \mathrm{HCl}$ aqueous solution (Fig. 9(b)), the amorphous alloy ribbon still displays passivation, but the passive region is very narrow and transpassivation occurs at a potential of about $0.1 \mathrm{~V}$, indicating the instability of passive film. Although it has a low corrosion current density of about $10^{-3} \mathrm{~A} / \mathrm{m}^{2}$, its corrosion resistance is not good because it would undergo active dissolution at the potential of above $0.1 \mathrm{~V}$. The corrosion behavior of the coating is very similar to that of the ribbon, but it almost has no passivation and its corrosion resistance is slightly bad.

The corrosion property of these samples in simulated seawater (Fig. 9(c)) is similar to those in $0.1 \mathrm{kmol} / \mathrm{m}^{3} \mathrm{HCl}$ aqueous solution. The ribbon has a slightly wider passive region in $3.5 \% \mathrm{NaCl}$ aqueous solution than that in $0.1 \mathrm{kmol} /$ $\mathrm{m}^{3} \mathrm{HCl}$ aqueous solution, but the transpassive potential is only at about $0.2 \mathrm{~V}$. It exhibits no distinct passivation for the coating, either. The corrosion current density for the ribbon and coating is nearly same as that in $0.1 \mathrm{kmol} / \mathrm{m}^{3} \mathrm{HCl}$ aqueous solution. Generally, the ribbon and coating have 

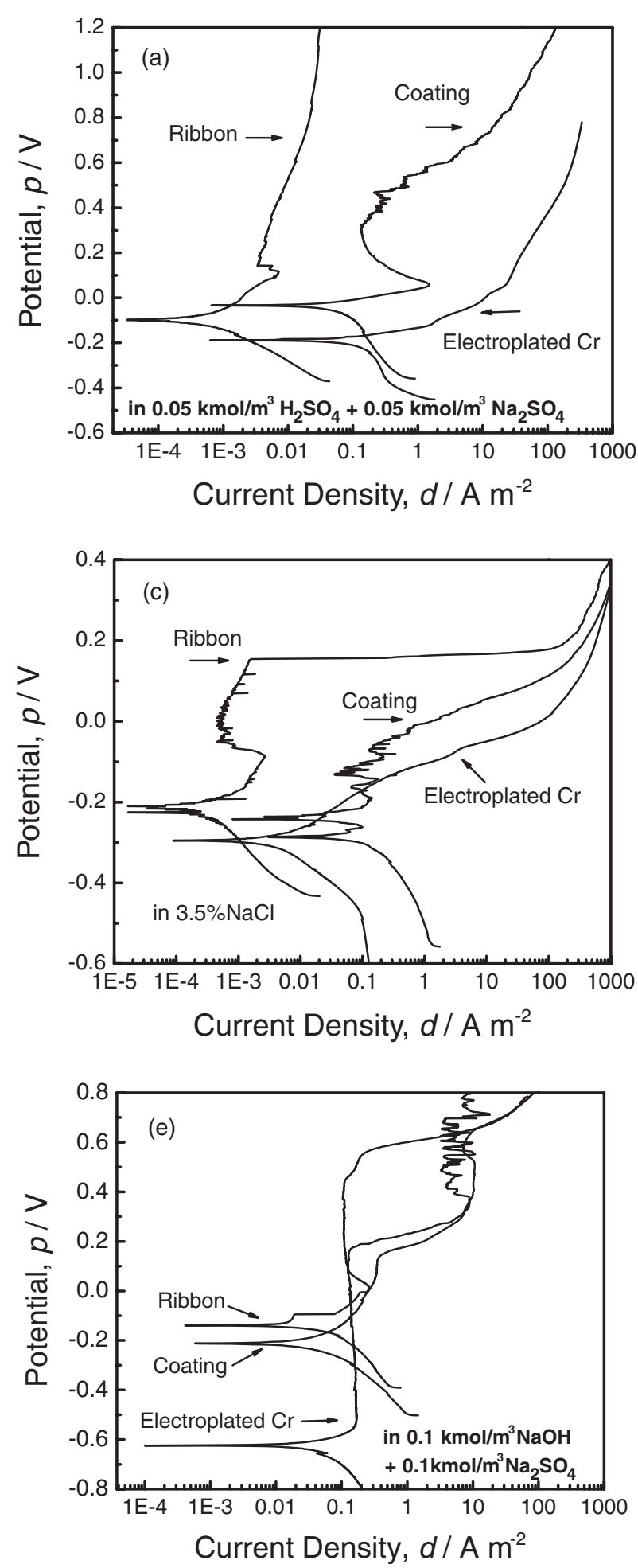

better corrosion resistance in $3.5 \% \mathrm{NaCl}$ aqueous solution than those in $0.1 \mathrm{kmol} / \mathrm{m}^{3} \mathrm{HCl}$ aqueous solution.

In alkali aqueous solutions (Figs. 9(d)-(e)), the corrosion resistance of the coating is comparable to the amorphous alloy ribbon of same composition. The homogenous structure of the amorphous alloy ribbon seems not to endow it better resistance to corrosion than the crystallized and oxidated coating. In this condition, it might support the idea that it is the alloy composition and not the amorphous state per se that dictates the corrosion properties of amorphous alloy. ${ }^{17)}$ Both the ribbon and coating exhibit active dissolution with the
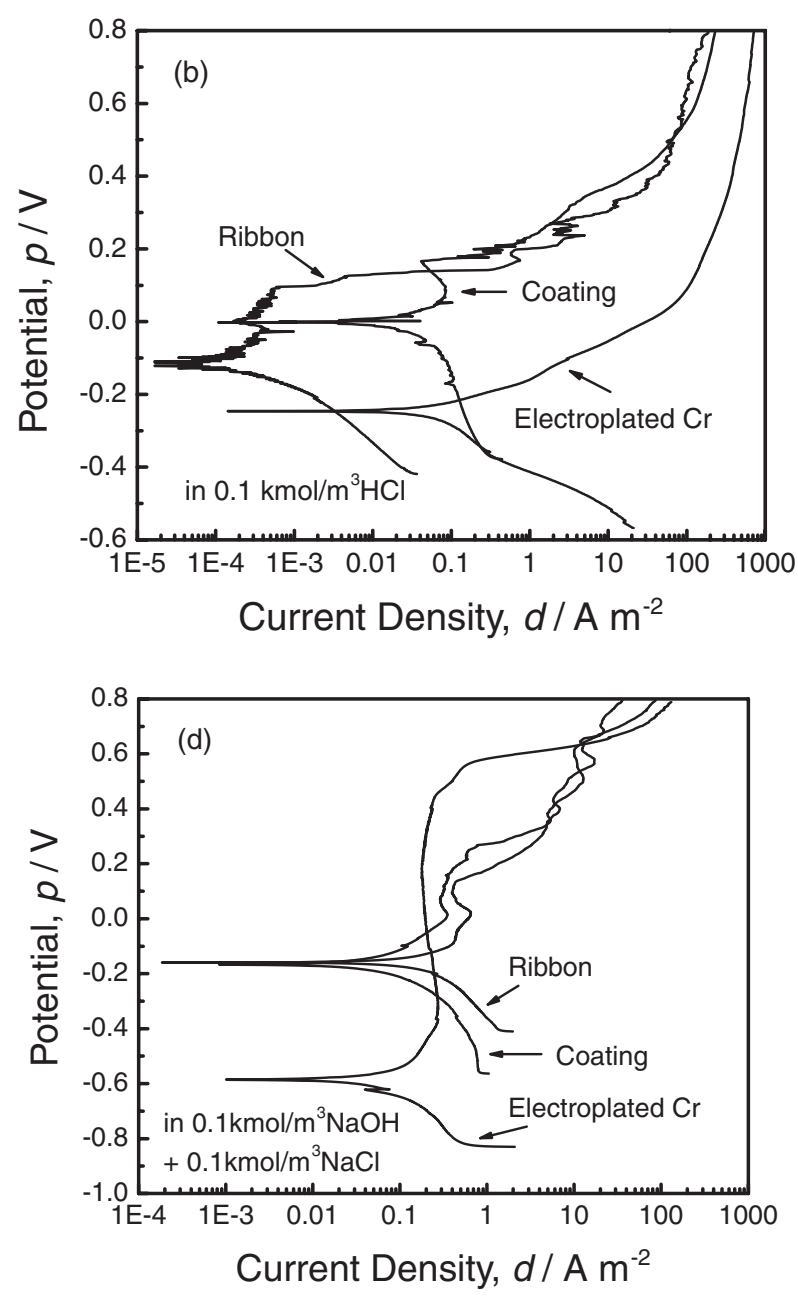

Fig. 9 Potentiodynamic polarization curves of the $\mathrm{Ni}_{59} \mathrm{Zr}_{20} \mathrm{Ti}_{16} \mathrm{Si}_{2} \mathrm{Sn}_{3}$ amorphous alloy ribbon, coating and the electroplated $\mathrm{Cr}$ samples in: (a) $0.05 \mathrm{kmol} / \mathrm{m}^{3} \mathrm{H}_{2} \mathrm{SO}_{4}+0.05 \mathrm{kmol} / \mathrm{m}^{3} \mathrm{Na}_{2} \mathrm{SO}_{4}$, (b) $0.1 \mathrm{kmol} / \mathrm{m}^{3} \mathrm{HCl}$, (c) $3.5 \% \mathrm{NaCl}$, (d) $0.1 \mathrm{kmol} / \mathrm{m}^{3} \mathrm{NaOH}+0.1 \mathrm{kmol} / \mathrm{m}^{3} \mathrm{NaCl}$, and (e) $0.1 \mathrm{kmol} / \mathrm{m}^{3} \mathrm{NaOH}+0.1 \mathrm{kmol} / \mathrm{m}^{3} \mathrm{Na}_{2} \mathrm{SO}_{4}$ aqueous solutions.

increasing potential, indicating their low corrosion resistance.

When the coating and amorphous alloy ribbon are compared with the electroplated $\mathrm{Cr}$ samples (Fig. 9), we can see that the electroplated $\mathrm{Cr}$ exhibits high corrosion resistance in alkali aqueous solutions because of low passive current density and wide passive region, but its corrosion resistance is bad in acid and simulated seawater solutions. In general, the corrosion properties of the coating and ribbon are better in acid and simulated seawater solutions, but worse in alkali aqueous solutions than the electroplated $\mathrm{Cr}$. 


\section{Conclusions}

Fully amorphous alloy powders with a size of smaller than $50 \mu \mathrm{m}$ produced by gas atomization and partial amorphous metallic coating due to crystallization and oxidation of the amorphous alloy powders during the HVAF thermal spraying were obtained. The amorphous metallic coating exhibits low porosity and good composition distribution along its depth.

The wear resistance of the coating has one order lower than the amorphous alloy ribbon of same composition; however, it is still higher than the electroplated $\mathrm{Cr}$.

The corrosion characteristics of the coating are sensitive to aqueous solutions selected. It exhibits good corrosion resistance in $0.05 \mathrm{kmol} / \mathrm{m}^{3} \mathrm{H}_{2} \mathrm{SO}_{4}+0.05 \mathrm{kmol} / \mathrm{m}^{3} \mathrm{Na}_{2} \mathrm{SO}_{4}$ aqueous solution due to low passive current density and wide passive region.

\section{Acknowledgments}

The authors acknowledge financial support from the National Natural Science Foundation of China (grant no. 50021101, 50271070, and 50323009). The stimulating discussions with Prof. Y. Li are greatly appreciated.

\section{REFERENCES}

1) A. L. Greer: Science 267 (1995) 1947-1953.

2) W. L. Johnson: JOM. March (2002) 40-43.

3) W. L. Johnson: Mater. Res. Soc. Symp. Proc. 554 (1999) 311-339.

4) J. F. Loeffler: Intermetallics 11 (2003) 529-540.

5) A. L. Greer, K. L. Rutherford and I. M. Hutchings: Int. Mater. Rev. 47 (2002) 87-112.

6) T. Gloriant: J. Non-Cryst. Solids 316 (2003) 96-103.

7) S. J. Pang, T. Zhang, K. Asami and A. Inoue: Mater. Trans. 43 (2002) 1771-1773.

8) S. J. Pang, T. Zhang, K. Asami and A. Inoue: Acta Mater. 50 (2002) 489-497.

9) A. H. Dent, A. J. Horlock, D. G. McCartney and S. J. Harris: Surf. Coat. Technol. 139 (2001) 244.

10) S. Sampath: Mater. Sci. Eng. A 167 (1993) 1-10.

11) F. Otsubo, H. Era, K. Kishitake and H. Matsumoto: ITSC'98, 279-283.

12) J. K. Lee, D. H. Bae, S. Yi, W. T. Kim and D. H. Kim: J. Non-Cryst. Solids 333 (2004) 212-220.

13) W. J. Trompetter, A. Markwitz and M. Hyland: Nucl. Instrum. Methods Phys. Res. B 190 (2002) 518-523.

14) Ronald W. Smith and Richard Knight: JOM. August (1995) 32-39.

15) Ronald W. Smith and Richard Knight: JOM. April (1996) 16-19.

16) E. Rabinowitz, L. A. Dunn and P. G. Russel: Wear 4 (1961) 345-355.

17) V. Schroeder, C. J. Gilbert and R. O. Ritchie: Scr. Mater. 38 (1998) 1481 . 